\title{
Study of Atmospheric Forcing and Responses (SAFAR) campaign: overview
}

\author{
A. Jayaraman, M. Venkat Ratnam, A. K. Patra, T. Narayana Rao, S. Sridharan, M. Rajeevan, H. Gadhavi, \\ A. P. Kesarkar, P. Srinivasulu, and K. Raghunath
}

National Atmospheric Research Laboratory, Gadanki 517112, India

Received: 25 June 2009 - Revised: 15 October 2009 - Accepted: 21 October 2009 - Published: 18 January 2010

\begin{abstract}
Study of Atmospheric Forcing and Responses (SAFAR) is a five year (2009-2014) research programme specifically to address the responses of the earth's atmosphere to both natural and anthropogenic forcings using a host of collocated instruments operational at the National Atmospheric Research Laboratory, Gadanki $\left(13.5^{\circ} \mathrm{N}, 79.2^{\circ} \mathrm{E}\right)$, India from a unified viewpoint of studying the vertical coupling between the forcings and responses from surface layer to the ionosphere. As a prelude to the main program a pilot campaign was conducted at Gadanki during May-November 2008 using collocated observations from the MST radar, Rayleigh lidar, GPS balloonsonde, and instruments measuring aerosol, radiation and precipitation, and supporting satellite data. We show the importance of the large radiative heating caused by absorption of solar radiation by soot particles in the lower atmosphere, the observed high vertical winds in the convective updrafts extending up to tropopause, and the difficulty in simulating the same with existing models, the upward traveling waves in the middle atmosphere coupling the lower atmosphere with the upper atmosphere, their manifestation in the mesospheric temperature structure and inversion layers, the mesopause height extending up to $100 \mathrm{~km}$, and the electro-dynamical coupling between mesosphere and the ionosphere which causes irregularities in the ionospheric F-region. The purpose of this communication is not only to share the knowledge that we gained from the SAFAR pilot campaign, but also to inform the international atmospheric science community about the SAFAR program as well as to extend our invitation to join in our journey.
\end{abstract}

Keywords. Ionosphere (Ionosphere-atmosphere interactions) - Meteorology and atmospheric dynamics (Middle atmosphere dynamics; Radiative processes)

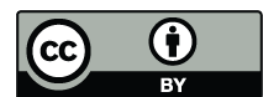

Correspondence to: A. Jayaraman (jayaraman@narl.gov.in)

\section{Introduction}

Earth's tenuous atmosphere is forced from above and below by natural as well as by a variety of human activities. Examples of forcings from above are: variations in solar radiation input, meteor shower which are natural, while falling space debris from above is the result of human activity. Similarly volcanic eruptions, earthquakes, cyclones, forest fires etc are examples of natural forcings from below while pollutant emission is a major manmade forcing. The atmosphere responds to these forcings in varying degrees and the responses could be different at different layers of the atmosphere. One of the serious concerns in atmospheric science is in minimizing the uncertainty in predicting the future state of the atmosphere if the current level of polluting the atmosphere continues unabated. However, for delineating anthropogenic forcing and its subsequent impact on weather and climate it is necessary to study the relative roles of various forcing mechanisms and their effects at different layers of the atmosphere as the entire atmospheric column behaves as one coupled system. Atmospheric response for one particular forcing in one region can have feedback effect and can act as a forcing in another region, making it often difficult to distinguish the causes and effects.

There have been several earlier studies carried out using a variety of powerful techniques such as the MST (Mesosphere-Stratosphere-Troposphere) radar, lidar operational at National Atmospheric Research Laboratory (NARL), Gadanki, which advanced our knowledge by providing valuable information on various cross related issues such as convective activities (e.g., Rao et al., 2009), atmospheric waves (e.g., Ratnam et al., 2008a), temperature structure (e.g., Kumar et al., 2009), ionospheric irregularities (e.g., Patra et al., 2004, 2005) etc. However, the main limitations were: most of them were case studies but for a few studies (e.g., Ratnam et al., 2008b; Sridharan et al., 2009) which dealt with long-term data base, but done independently for

Published by Copernicus Publications on behalf of the European Geosciences Union. 


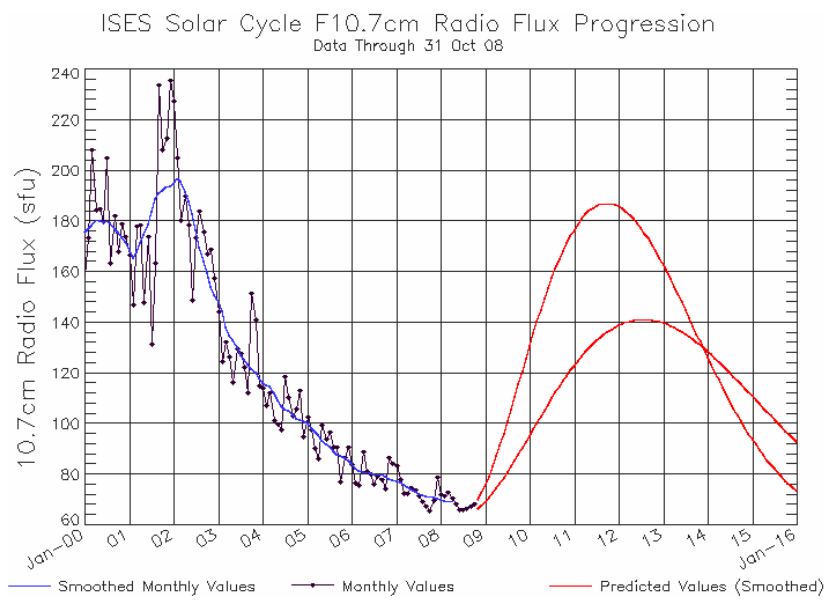

Fig. 1. F10.7 $\mathrm{cm}$ radio flux observed (2000 to 2008) and predicted (2009-2016) values (source: NOAA).

different height regions of the atmosphere. Sufficient statistics is still not available for various scales of waves. Also, campaigns conducted earlier did not consider studying the behaviour of the entire atmosphere in unison from surface layer to upper atmosphere. Study of Atmospheric Forcing and Responses (SAFAR ${ }^{1}$ ) aims at filling this void, and attempts to quantify the responses of the atmosphere as a whole to any external disturbances whether natural or manmade. SAFAR is conceived as a journey through space, from surface layer to the ionosphere, and time to understand and predict the interrelationship between various responses of the atmosphere to a variety of related and unrelated forcings both by natural and manmade means.

\section{SAFAR outine}

SAFAR is a research program spearheaded by the scientists of NARL, Gadanki, India, an autonomous unit of Department of Space, Government of India, and proposed to be run initially for about five years (2009 to 2014) and later for an extended period, while a pilot campaign has already been completed in 2008. NARL is well equipped with a wide range of techniques for probing the entire column of the atmosphere such as the MST radar, lidars, daily GPS balloonsonde launch, aerosols, radiation and precipitation measuring equipments, automatic weather station etc. In order to address various aspects of the atmospheric processes, the entire study is divided into four main study themes: Theme 1 relates to the study of convective activities in and around Gadanki and its role in the Stratosphere-Troposphere Exchange (STE) processes; Theme 2 addresses the aerosols, ra-

\footnotetext{
${ }^{1}$ SAFAR in Hindi, one of the Indian languages, means journey. In the present context it is a journey through space (from surface layer to ionosphere) and time, from year 2009 to 2014 , the study period.
}

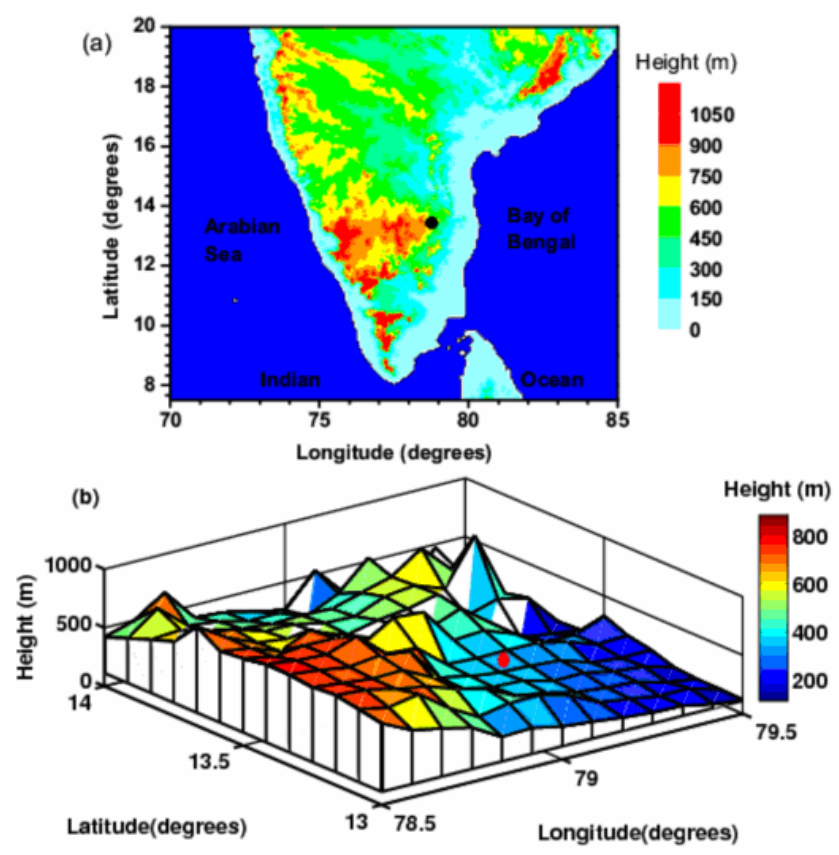

Fig. 2. (a) Topography map of peninsular India (EROS data). Filled circle shows the location of NARL, Gadanki $\left(13.5^{\circ} \mathrm{N}, 79.2^{\circ} \mathrm{E}\right.$, $335 \mathrm{~m}$ above m.s.l.) where SAFAR campaign is being carried out. (b) High resolution topography map for $50 \mathrm{~km}$ radius around Gadanki.

diation and trace gases forcing of the atmosphere; Theme 3 focuses on the impact of lower atmospheric radiative and convective forcings on middle atmospheric dynamics, and Theme 4 examines the upper mesosphere and lower thermospheric responses to lower atmospheric forcings and forcings from above. The pilot campaign conducted during 2008 addressed some of the above issues and helped to prepare ourselves for an intensive campaign, which has started since early 2009. As the solar activity is currently the minimum (Fig. 1), it is thought ideal to start the main campaign, so as to record the atmospheric responses to solar induced forcing from above, from solar minimum to maximum, in comparison to atmospheric forcings from below.

\section{Measurement location and methodology}

\subsection{Site description}

The measurement site is NARL located in a village, Gadanki $\left(13.5^{\circ} \mathrm{N}, 79.2^{\circ} \mathrm{E}\right.$, and $335 \mathrm{~m}$ above m.s.1.) (Fig. 2). The site is surrounded by hills, specifically chosen because of its very low background radio noise suitable for carrying out the MST radar observations. The weather is typical for tropics with daytime maximum temperature varying between $26^{\circ} \mathrm{C}$ (December) and $36^{\circ} \mathrm{C}$ (April) and nighttime minimum temperature varying between $15^{\circ} \mathrm{C}$ (January) and $24^{\circ} \mathrm{C}$ (May). The total annual rainfall is about $90 \mathrm{~cm}$ which comes from both the summer (southwest) monsoon which is active during 
June to September and winter (northeast) monsoon from October to December.

\subsection{Instruments and techniques}

SAFAR demands continuous observations from surface to upper atmosphere for studying the vertical coupling between different layers of the atmosphere for which a good set of ground based instruments with complementary techniques collocated at one location is necessary. Table 1 gives the list of instruments available at NARL and the approximate altitude range covered by each instrument. Though height coverage of each instrument is limited, they, however complement each other and cover the entire atmospheric column from surface layer to the ionosphere. The core instruments for the SAFAR campaign are MST radar and Lidar. MST radar is a $53 \mathrm{MHz}$ high power coherent pulsed Doppler radar, consisting of collocated two independent sets of 1024 three-element Yagi antennas and occupying an area of $130 \mathrm{~m} \times 130 \mathrm{~m}$ with maximum peak power of about $2.5 \mathrm{MW}$. It measures 3-D wind profiles from about $1.5 \mathrm{~km}$ up to $21 \mathrm{~km}$ in troposphere and lower stratosphere, 65 to $85 \mathrm{~km}$ in mesosphere, and ionospheric irregularity echoes from E- and F-regions. Complete system details are available in Rao et al. (1995). The Rayleigh lidar system available at NARL uses high power Nd:YAG laser source $(600 \mathrm{~mJ} /$ pulse with $50 \mathrm{~Hz}$ PRF) and a $75 \mathrm{~cm}$ diameter telescope to study the vertical temperature profile from about 30 to $80 \mathrm{~km}$ and aerosols and cirrus clouds below $30 \mathrm{~km}$. With this high power lidar system investigation of mesospheric temperature inversion layers is possible. Surface level meteorological data are obtained from instruments such as Automatic Weather Station, radiometer, rain gauge, and disdrometer. GPS balloon radiosonde are regularly launched every day around 12:00 UT to obtain wind speed, direction, temperature and relative humidity profiles up to a height of about $32 \mathrm{~km}$ (typical balloon burst altitude). In addition extra sondes are launched during major convective events. Balloons are also launched four times a day during Intensive Observations Period (IOP) for 3 days in each month when MST radar is also operated continuously to capture short period gravity wave events. For aerosols and radiation studies a host of instruments such as the Boundary Layer Lidar (BLL) for measuring aerosol extinction profile, boundary layer height, cloud base height, optical depth for optically thin clouds etc., sky-radiometer for columnar aerosol optical depth at multiple wavelengths, Nephelometer for surface level aerosol total and backscattering coefficients at three wavelengths, Aethalometer for black carbon concentration, and aerodynamic particle sizer for aerosol size distribution are being used. Optical rain gauge and disdrometer are used for monitoring rainfall rate and rain drop size distribution. Apart from these measurements made using instruments available at the site, complementary satellite data from INSAT, NCEP/NOAA data products, GPS RO, SABER, MODIS, MISR, OMI, CloudSat data are also used.

\subsection{SAFAR Pilot campaign}

The SAFAR pilot campaign was conducted during May to November 2008 with a view to bring out the important science issues and to identify the missing links in terms of observations and data so as to prepare us for the main campaign. While various instruments listed in Table 1 are operated during the campaign period, data from optical instruments are intermittent due to cloudy sky condition as JuneSeptember months is a period of active Indian summer monsoon. May, June, October and November months are dedicated to study convective events and associated perturbations in meteorological parameters. More than a dozen convective events were recorded during the pilot campaign in which more than half were associated with rainfall. During other months, radar was operated for 10 days in lower atmospheric mode and immediate next days in upper atmospheric mode. Upper atmospheric observations were done during new moon period so as to coordinate with Rayleigh Lidar observations. GPS radiosondes were released every day around 12:00UT and for every $6 \mathrm{~h}$ during the IOP when convective activity was strong over the site. This overview paper is aimed at bringing the importance of a sustained study using collocated instruments as well as complementary data from satellites, by discussing various science issues related to atmospheric forcings and responses. The science issues are discussed using a few selected results obtained from the SAFAR pilot campaign, while the companion papers in this issue give details of specific studies carried out.

\section{Science issues}

\subsection{Radiative forcing}

One of the prime concerns in addressing climate change is quantifying the impact of anthropogenic emissions of aerosols and trace gases which alter the earth's radiation budget. With increasing man-made activities there is an unprecedented increase in the amount of aerosols and a variety of trace gases in the atmosphere. Atmospheric aerosols and trace gases change the earth's radiation budget both temporally and spatially by scattering, absorbing and emitting radiation, which in turn influence the energy budget and hence the climate of the earth. As aerosols and trace gases are transported over long distances, their chemical and radiative effects are not only confined to their source regions but extend to larger regional scales. Estimating the role of aerosols and trace gases quantitatively in altering the earth's radiation budget is the key to understand the earth's climate and its future evolution.

Information on aerosol optical depth, single scattering albedo and asymmetry parameter are fundamental to estimate aerosol radiative forcing, while information on vertical distribution of aerosol properties are needed to estimate 
Table 1. List of instruments with complementary techniques currently available at NARL, Gadanki, a tropical site in India to study the entire column of the earth's atmosphere as part of the SAFAR main campaign.

\begin{tabular}{|c|c|c|c|}
\hline Sr. No. & Instrument & $\begin{array}{l}\text { Parameter/s measured or derived and ap- } \\
\text { prox. altitude coverage }\end{array}$ & Operation schedule \\
\hline 1 & MST radar & $\begin{array}{l}\text { 3-D wind profiles from about } 1.5 \mathrm{~km} \text { to } \\
\text { about } 21 \mathrm{~km} \text { and from } 65 \text { to } 85 \mathrm{~km} \text {, and } \\
\text { ionospheric echoes from the E- and F- } \\
\text { regions }\end{array}$ & $\begin{array}{l}\text { Regular day and night observations in } \\
\text { lower and upper atmospheric modes }\end{array}$ \\
\hline 2 & Mie and Rayleigh Lidar & $\begin{array}{l}\text { Aerosols, cirrus clouds up to tropopause } \\
\text { altitude }(\sim 17 \mathrm{~km}) \text { and temperature profile } \\
\text { from } 30 \text { to } 80 \mathrm{~km}\end{array}$ & During all cloud free nights \\
\hline 3 & Boundary layer lidar & $\begin{array}{l}\text { Aerosol extinction profile, Boundary layer } \\
\text { height, Cloud base height, Optical depth for } \\
\text { optically thin clouds up to } 20 \mathrm{~km}\end{array}$ & Routine observation. \\
\hline 4 & GPS balloon Radiosonde & $\begin{array}{l}\text { Wind speed, Direction, Temperature and } \\
\text { Relative humidity profiles up to balloon } \\
\text { burst altitude, typically } 32 \mathrm{~km}\end{array}$ & $\begin{array}{l}\text { Daily one launch at } 12: 00 \mathrm{UT} \text { and during } \\
\text { convective events every } 6 \text { hourly spreading } \\
\text { to about } 3 \text { days }\end{array}$ \\
\hline 5 & SODAR & 3-D wind profiles up to $700 \mathrm{~m}$ & Routine observations \\
\hline 6 & $\begin{array}{l}\text { Radio Acoustic Sounding System } \\
\text { (RASS) }\end{array}$ & $\begin{array}{l}\text { Continuous temperature profile for every } \\
30 \text { min up to tropopause during both day } \\
\text { and night time conditions }\end{array}$ & Only in campaign mode \\
\hline 7 & $\begin{array}{l}\text { Automatic Weather Station } \\
\text { (AWS) } 50 \mathrm{~m} \text { tower }\end{array}$ & $\begin{array}{l}\text { Temperature, Relative humidity, wind } \\
\text { speed and direction up to } 50 \mathrm{~m}\end{array}$ & Routine observations \\
\hline 8 & Optical Rain gauge (ORG) & Rainfall rate and amount & $"$ \\
\hline 9 & Disdrometer & Rain drop size distribution & $"$ \\
\hline 10 & GPS Receiver & $\begin{array}{l}\text { Total Electron Content and Integrated Wa- } \\
\text { ter Vapour }\end{array}$ & $”$ \\
\hline 11 & Ionosonde & $\begin{array}{l}\text { Electron density profile up to the } \mathrm{F} \text { region } \\
\text { peak; sporadic } \mathrm{E} \text { and spread } \mathrm{F} \text { observations }\end{array}$ & $"$ \\
\hline 12 & Magnetometer & Surface magnetic field & $"$ \\
\hline 13 & Airglow photometer & $\begin{array}{l}\text { Airglow emissions from } \mathrm{OH}(840 \mathrm{~nm}) \text { and } \\
\mathrm{O}_{2}(866 \mathrm{~nm}) \text { from } 85 \text { and } 94 \mathrm{~km} \text {, respec- } \\
\text { tively }\end{array}$ & Routine nighttime observations \\
\hline 14 & $\begin{array}{l}\text { Pyranomter and Pyrheliometer } \\
\text { (Kipp and Zonen) }\end{array}$ & $\begin{array}{l}\text { Surface reaching direct solar, global and } \\
\text { diffuse radiations }\end{array}$ & Routine daytime observations \\
\hline 15 & Skyradiometer (Prede) & $\begin{array}{l}\text { Aerosol optical depth at five wavelengths, } \\
\text { Column average single scattering albedo } \\
\text { and size distribution, Column ozone } \\
\text { amount, and precipitable water vapour }\end{array}$ & $"$ \\
\hline 16 & Nephelometer (TSI Inc.) & $\begin{array}{l}\text { Aerosol total and back scattering coeffi- } \\
\text { cients at three wavelengths }\end{array}$ & $\begin{array}{l}\text { Every five minutes; day and night continu- } \\
\text { ous }\end{array}$ \\
\hline 17 & Aethalometer (Magee Sci.) & $\begin{array}{l}\text { Black carbon concentration, Absorption } \\
\text { coefficient at seven wavelengths }\end{array}$ & , \\
\hline 18 & $\begin{array}{l}\text { Aerodynamic Particle Sizer (TSI } \\
\text { Inc.) }\end{array}$ & Aerosol size distribution & $"$ \\
\hline \multicolumn{4}{|c|}{ Other data } \\
\hline 19 & Doppler Weather Radar & Cloud structure and motion & $\begin{array}{l}\text { Operated at Chennai (about } 130 \mathrm{~km} \text { south } \\
\text { east of Gadanki) by the India Met Dept. }\end{array}$ \\
\hline 20 & Satellite observations & $\begin{array}{l}\text { INSAT, NCEP/NOAA data products, GPS } \\
\text { RO, SABER, MODIS, MISR, OMI, Cloud- } \\
\text { Sat data }\end{array}$ & Obtained from external agencies \\
\hline
\end{tabular}


atmospheric heating due to aerosols. The information of size distribution and black carbon concentration can provide insight into anthropogenic aerosol radiative forcing. Correlation with various trace gases can further provide information on source and age of aerosols. One of the SAFAR objectives is to establish the typical diurnal and seasonal variations of aerosol characteristics over a typical Indian rural environment such as Gadanki and how the surface emission of pollutants and meteorology influences the aerosol concentration and its vertical distribution. Using the measured aerosol characteristics and standard radiative transfer model aerosol radiative forcing is computed, while attempt is made to delineate the radiative forcing by anthropogenic aerosols. A complete set of aerosol and radiation measuring instruments are getting established, of which data from the Prede sunphotometer on aerosol optical depth and Aethalometer data on soot concentration and spectral characteristics of aerosol absorption coefficient are now available for the period April to November 2008 covering fully the summer monsoon period of June to September.

One of the important findings is the significant contribution of aerosols from biomass burning, typical of rural region, to the radiative forcing. There are two types of biomass burning: one is burning biofuel such as wood for normal day to day cooking which is a daily phenomenon, and the other one is burning large junk of agricultural waste in open fields, mainly confined to dry months (March to May) prior to the setting in of summer monsoon rain, a way of making the field ready for next sowing. Soot particles produced from incomplete combustion is known for their absorption of solar radiation, which add to the greenhouse warming of the atmosphere (IPCC, 2007). The intriguing part of soot produced from biomass burning, is that they exhibit higher spectral dependence $\left(\lambda^{-2}\right)$ in absorption compared to that produced from fossil fuel burning which has less wavelength dependence $\left(\lambda^{-1}\right)$, implying that the biomass burning produced soot has higher absorption at lower wavelengths leading to higher heating effect. We found that even in a relatively pristine environment like Gadanki, the background level of soot amount is about $1.5 \mathrm{mg} / \mathrm{m}^{3}$ of air during monsoon months which can go up to about $4 \mathrm{mg} / \mathrm{m}^{3}$ during April, May months when the burning of agriculture waste is high. More details on the diurnal and day to day variability in soot concentration and their contribution to aerosol radiative forcing are presented and discussed in an accompanying paper (Gadhavi and Jayaraman, 2009). Using standard radiative transfer calculations it is found that the higher soot amount in the premonsoon months (MAM) with higher absorption at lower wavelengths lead to a larger atmospheric radiative forcing of about $20 \mathrm{~W} / \mathrm{m}^{2}$ while during monsoon months (JJAS) the forcing is about $10 \mathrm{~W} / \mathrm{m}^{2}$ when the soot content in the atmosphere is low. The pre-monsoon value of $20 \mathrm{~W} / \mathrm{m}^{2}$ is comparable to $22 \pm 4 \mathrm{~W} / \mathrm{m}^{2}$ that was reported for the peninsular India for the dry season (Jayaraman et al., 2006). This leads to an additional heating of the lower atmosphere at the rate

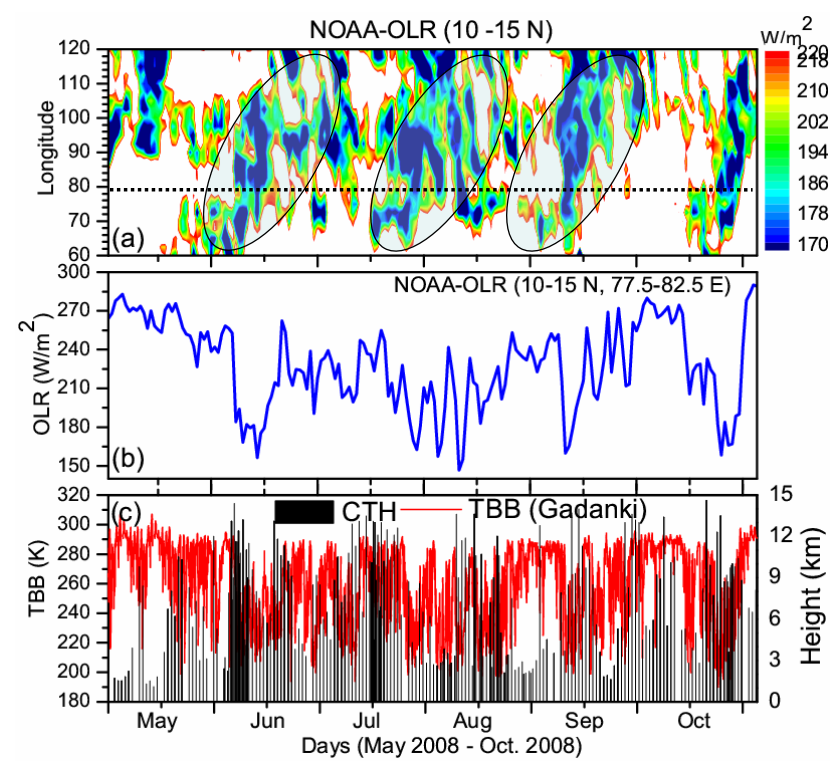

Fig. 3. (a) Time-longitude section of outgoing long-wave radiation (OLR) observed during May to October 2008 from NOAA interpolated data set averaged between $12.5-15^{\circ} \mathrm{N}$ latitudes. Ellipses are drawn to show the super cloud clusters passing through Gadanki longitude (horizontal dotted line). (b) Time series of OLR at Gadanki grid. (c) Brightness temperature (TBB) observed (red line) for every hour during above mentioned period and corresponding cloud top altitude (CTH, vertical bars) estimated using simultaneous GPS radiosonde data at 12:00 UT.

of about $0.5 \mathrm{~K} /$ day. The question we like to ask is how this increased radiative forcing and hence the additional heating get manifested in atmospheric dynamics in general and in convective activities in particular?

\subsection{Convective forcing}

Several interesting studies have been carried out earlier on convection and related processes using the suite of instrumentation available at NARL, including the MST Radar, Lower Atmospheric Wind Profiler (LAWP) and other surface measurements. These studies helped in advancing our knowledge on convection, in particular the structure and microphysics of convection. Nevertheless, one area which is not yet studied in detail is the energy budget associated with the convection. What kind of moist static energy is required for deep convection? What are the conditions ideal for the initiation of convection? Are there any potential barriers to inhibit the growth of convection? Many of these questions are yet to be answered. Uma and Rao (2009) have studied the MST radar data over Gadanki for about 60 convective system passages and shown that variation of vertical velocity distribution with height is different for different convection categories like shallow, deep and decaying convections. During deep convective systems strong updrafts in the 
upper troposphere with high vertical velocity of value above $10 \mathrm{~m} \mathrm{~s}^{-1}$ were observed over Gadanki.

Figure 3a shows the time-longitude section of outgoing long-wave radiation (OLR) representing the cloud top temperature observed during May to October 2008 from NOAA interpolated data set averaged between $12.5-15^{\circ} \mathrm{N}$ latitudes. Ellipses are drawn to show the super cloud clusters passing through Gadanki longitude $\left(79.2^{\circ} \mathrm{E}\right.$ shown by the horizontal dotted line). The OLR variation during the pilot campaign period over the Gadanki grid $\left(12.5-15.0^{\circ} \mathrm{N}, 78.5-80.0^{\circ} \mathrm{E}\right)$ is shown in Fig. 3b. At least three super cloud clusters passed over Gadanki during the pilot campaign period. Brightness temperature (TBB) observed over the Gadanki region $(5 \mathrm{~km} \times 5 \mathrm{~km})$ and corresponding cloud top altitude estimated using GPS radiosonde launches from Gadanki are shown in Fig. $3 \mathrm{c}$ which suggest that on an average cloud top altitudes are $12-13 \mathrm{~km}$ during these three supper cloud clusters. TBB data available for every hour with $5 \mathrm{~km} \times 5 \mathrm{~km}$ grid shows strong convective events which are found to correlate with strong vertical velocities observed by the MST radar, suggesting that TBB data can be used as proxy for convection events over Gadanki (Ratnam et al., 2009).

As part of the SAFAR program now a new study has been initiated to examine the sensitivity of cloud microphysics in the simulation of updrafts observed by the MST radar over Gadanki. As a case study, Weather Research and Forecasting (WRF) model version 3.0 has been used to simulate the convective updrafts associated with a thunderstorm observed over Gadanki on 21 May 2008 (Rajeevan et al., 2009). Four different cloud microphysics schemes have been used to study their sensitivity in simulating the updraft and downdraft properties associated with the thunderstorm. Among the four schemes, the Thompson Scheme (Thompson et al., 2004) and the Purdue Lin Scheme (Chen and Sun, 2002) were able to simulate the observed features with less uncertainty compared to the other single moment six-class (WSM6) scheme (Hong et al., 2004) and double moment Morrison Scheme (Morrison et al., 2005) simulations. Even in the Thompson and Lin schemes simulations there are differences as the observed vertical extend and the magnitude of the updrafts were higher than the simulations implying the sensitivity of parameterization of various microphysical processes used in these models. For example, the observed updrafts associated with the convective storm were found to extend up to about $14 \mathrm{~km}$, with the maximum updraft velocity exceeding $4 \mathrm{~m} \mathrm{~s}^{-1}$ at around $10.5 \mathrm{~km}$. However even in the best simulation the vertical extend of the draft was limited to around $12 \mathrm{~km}$ and the maximum updraft was about $1.5 \mathrm{~m} \mathrm{~s}^{-1}$ at around $8 \mathrm{~km}$. Overall the magnitude of the simulated updraft velocity is much smaller compared to the MST radar observations at all altitudes. The role of aerosols and the additional heat caused by them through radiation absorption need to be parameterized in a more realistic way taking into account the actual aerosol characteristics which are region specific. This shows the importance of multi-observational platforms of different but related parameters to make better parameterization schemes in order to bridge the gap between the observation and model simulation. Use of dual polarization lidar for studying cloud properties which can distinguish spherical water droplets from non-spherical ice crystals, and simultaneous study of the vertical profiles of thermodynamic parameters are given special emphasis in the SAFAR main campaign with a view to improve parameterizations of atmospheric convection and cloud microphysics.

The exchange of mass and energy between the troposphere and stratosphere over tropics during deep convective updrafts is another important area, which needs to be understood in detail. As the tropical tropopause altitude is high and the temperature is the coldest, it is general wisdom that the air entering into the stratosphere through overshooting convective turrets is exposed to these extremely cold temperatures resulting into the formation of ice that will sediment out leaving dry air to enter the stratosphere (Sherwood and Dessler, 2001). Also there are studies (e.g. Corti et al., 2008) which argue that convection can hydrate the stratosphere through evaporation of condensates and turbulent mixing in the upper troposphere lower stratosphere (UTLS) region. Although there are several studies to quantify the turbulence at various altitudes of the troposphere they were done mainly during fair weather condition. As part of the SAFAR pilot campaign a deliberate attempt has been made to quantify the turbulence in the UTLS region when convection is active. The MST radar was used to measure the vertical air velocity $(w)$ and spectral width $(\sigma)$, optical rain gauge (ORG-815) was used to obtain surface rainfall rate $(R)$ at every minute, and concurrent balloon borne radiosonde (Meisei-RS01GH) measurements for retrieval of air density $(\rho)$ profiles. About 16 convection events ( 10 deep and 6 shallow) were observed during the pilot campaign period of which five cases were studied and two events (21 May 2008 and 24 September 2008) are discussed in detail in a companion paper (Rao et al., 2009). The gist of the findings is that the updraft cores were found penetrating into the stratosphere. The mean mass flux per unit volume estimated from $w$ and $\rho$ values in the height region of $16-20 \mathrm{~km}$ are $0.21 \pm 0.14 \mathrm{~kg} \mathrm{~m}^{-2} \mathrm{~s}^{-1}$ for upward mass flux and $0.11 \pm 0.07 \mathrm{~kg} \mathrm{~m}^{-2} \mathrm{~s}^{-1}$ for downward flux. The large upward flux shows that the STE process over tropics is mainly from troposphere to stratosphere. Apart from the direct transport through overshooting convection, the exchange also occurs through turbulence diffusion. The distribution of spectral width in draft cores near the vicinity of the tropopause is a measure of turbulence. The mean spectral width at the tropopause for draft cores is found to be $1.82 \pm 0.96 \mathrm{~m} \mathrm{~s}^{-1}$ which is about 4.2 times larger than the fair-weather time value of $0.43 \pm 0.16 \mathrm{~m} \mathrm{~s}^{-1}$. However, spectral width larger than $4 \mathrm{~m} \mathrm{~s}^{-1}$ has also been found on a few occasions. If simultaneous water vapor profile is available in the UTLS region the hydration or dehydration of stratosphere could have been verified. In the SAFAR main campaign it is proposed to operate a water vapour Raman lidar to get the 

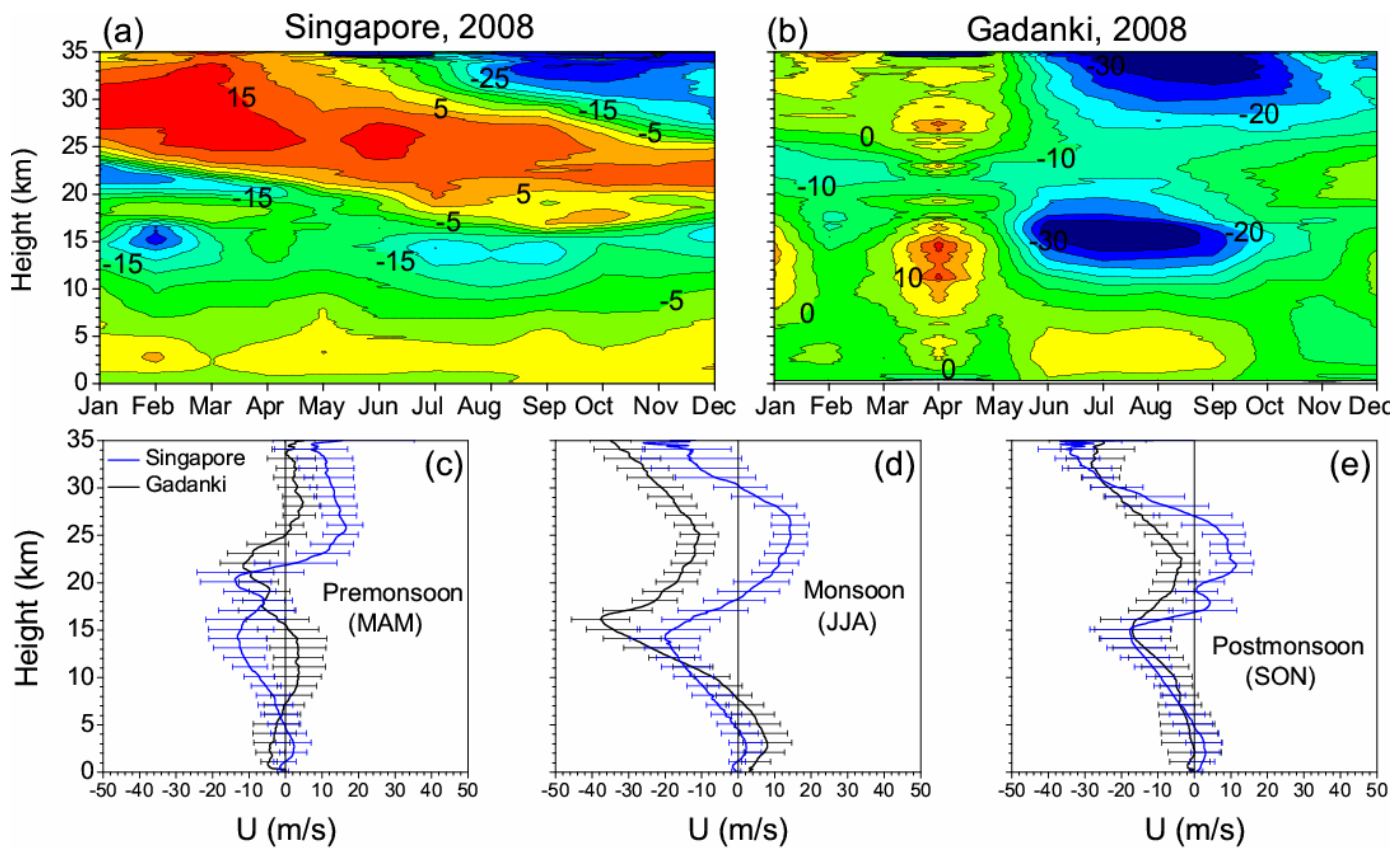

Fig. 4. Time-height section of zonal wind $\left(\mathrm{m} \mathrm{s}^{-1}\right)$ observed during January-December 2008 at (a) Singapore, (b) Gadanki. Mean profiles observed while averaging during (c) pre-monsoon, (d) monsoon, and (e) post-monsoon seasons for both Gadanki and Singapore.

required information. Indigenous development of the Raman lidar has already been initiated.

\subsection{Dynamical coupling}

Convective forcing from lower atmosphere will have a large impact in the middle atmosphere. One of the main objectives of SAFAR is to determine the structure and characteristics of various waves in the middle atmosphere and the coupling between the lower and upper atmosphere. Combining the MST radar, GPS balloon sonde, lidar and satellite observations it is possible to study the height and spatial variations of atmospheric wave dynamics, and in particular the vertical and horizontal propagation characteristics of various atmospheric waves and tides. The vertical coupling processes between different height layers through wave-wave and/or wave-mean flow is the main focus of the study. Some of the questions we like to ask are: what wave numbers can penetrate to higher altitudes; what is the extent of penetration of these waves into tropical and sub-tropical latitudes, and what is the behavior of short period gravity waves and planetary waves ( $<10$ day) in the stratosphere and mesosphere and their effect on the observed mesospheric temperature inversions and ionospheric irregularities etc. For example, convection and wind shear dominates during monsoon season and hence the question arises that which is the dominant source mechanism in generating gravity waves.

From the preliminary study conducted during the SAFAR pilot campaign, it is found that during monsoon season, vertical shears in zonal wind dominates in generating wide spec- trum of gravity waves right from short period $(30 \mathrm{~min}$ to $2 \mathrm{~h})$ to inertial periods $(51 \mathrm{~h})$ over Gadanki although strong convection co-exists (Ratnam et al., 2009). From our previous investigations (Debashis Nath et al., 2009) we could also notice wave activity during other seasons but in monsoon months the wave energy is found to be higher by 30 $40 \%$. Another interesting feature observed was the existence of strong diurnal variation in Topical Easterly Jet (TEJ) and in wind shears. Information on background wind conditions is very essential in order to study propagation characteristics of any waves. Until now there is a tendency to take winds observed over Singapore as typical for tropical latitudes. However, we find the wind features are quite different between Singapore and Gadanki. Figure $4 \mathrm{a}$ and $\mathrm{b}$ shows monthly mean zonal wind observed at Gadanki and Singapore, respectively, during January 2008 to December 2008. Long-period oscillations seen in both data sets differ largely, raising a question that how far is it applicable to use Singapore winds as representative data for all tropical latitudes? Figure $4 \mathrm{c}, \mathrm{d}$ and e shows the comparison for the pre-monsoon (MAM), monsoon (JJAS) and post-monsoon (ON) seasons. Quite opposite features are noticed in pre-monsoon. Influence of TEJ in zonal wind is seen over Gadanki but not over Singapore. More or less similar trends can be noticed in the post-monsoon season although they differ in direction and magnitudes in lower stratosphere. Wind observed between 20 and $30 \mathrm{~km}$ during monsoon months is easterly over Gadanki but it is westerly over Singapore. These different features in background wind will have different filtering 


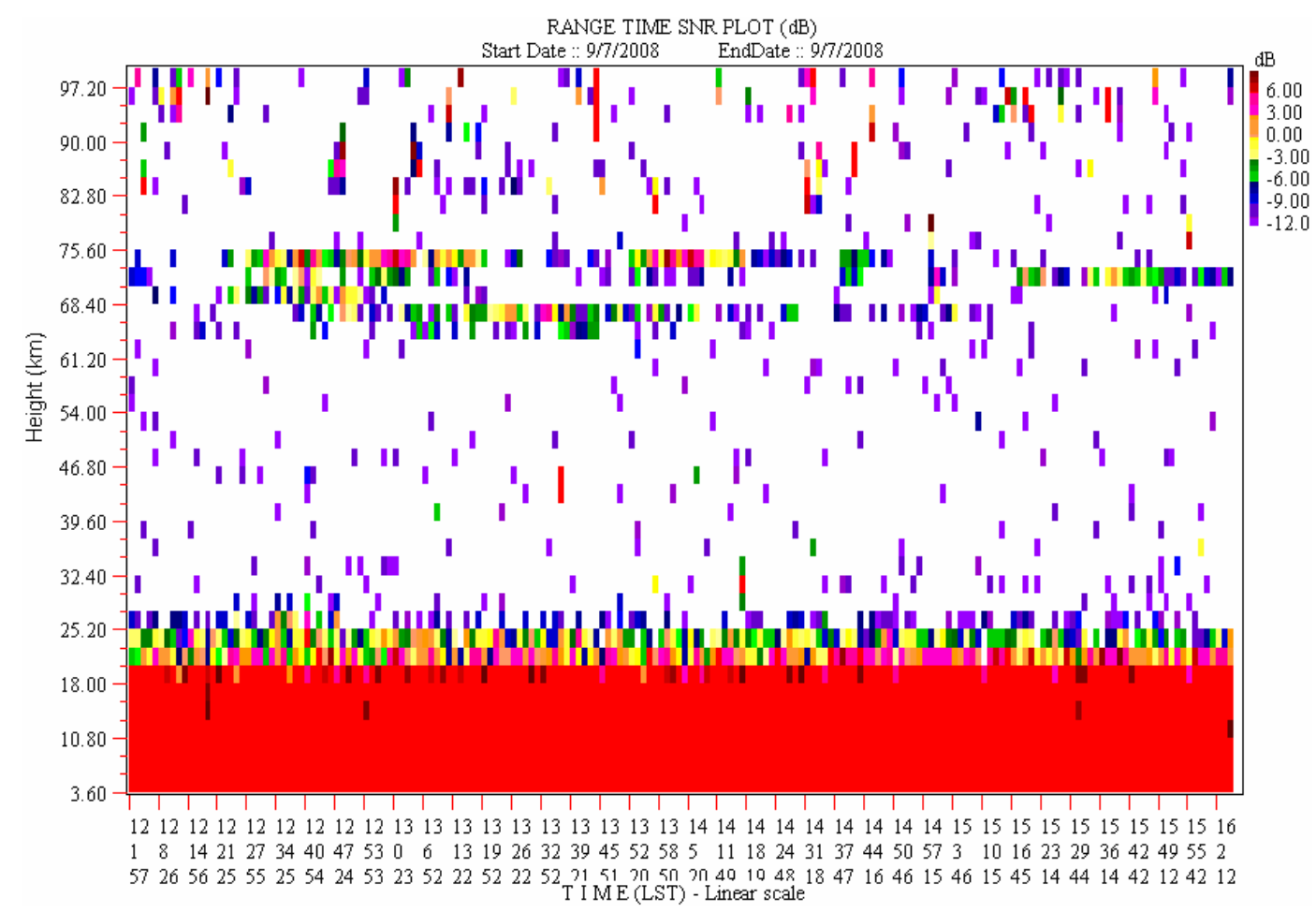

Fig. 5. Range-time SNR plot of mesospheric echoes observed by the MST radar (vertical beam) on 9 July 2008 over Gadanki.

processes on the waves propagating upwards. The importance of studying the wave propagation in the middle atmosphere and the dynamical coupling of the lower and upper atmosphere lies in the fact that the amount of energy transferred into the mesosphere by breaking of these waves is comparable to the amount of energy absorbed from the Sun (Meriwether and Gerrard, 2004) in this region. The transfer of momentum by these waves can drive the mesosphere out of radiative equilibrium and can alter the mesospheric thermal structure and meridional circulation.

Another interesting feature observed from long-term climatology (1995 to 2006) on mesospheric echoes using Indian MST radar is that more and strong echoes are observed during solar minimum and vice versa (Kumar et al., 2007) and a higher percentage of echoes occur during equinoxes followed by summer and minimum in winter (Ratnam et al., 2002; Kumar et al., 2007). However, we do not have supporting data sets to address this interesting phenomenon, and detailed experiments are planned under theme 3 of SAFAR. Typical examples showing almost continuous echoes appearing one around $67 \mathrm{~km}$ and other around $78 \mathrm{~km}$ observed on 9 July 2008 are shown in Fig. 5. An intriguing result is that although SAFAR pilot campaign coincides with low solar activity, the probability of echo occurrence and the echo strength are larger than those observed during the high solar activity reported earlier (Kumar et al., 2007). The cause of additional/intense turbulence during the low solar activity period needs to be investigated. Detailed case studies has to be carried out to address specifically why mesospheric echoes confined to narrow width of $10 \mathrm{~km}$ occurring in between 65 and $80 \mathrm{~km}$, why often two layers with separation of around $10 \mathrm{~km}$ occur. Coordinated measurements as part of SAFAR from 2009 (solar minimum) to 2014 (predicted solar maximum) is expected to answer some of these questions.

Inversion layers of vertical thickness of about $10 \mathrm{~km}$, which can last for a few days, can frequently occur in the mesosphere. So far two mechanisms have been invoked to account for the inversions: dynamical and chemical heating. Recently Sridharan et al. (2008) showed the influence of tides and gravity waves on the formation of the inversion layers observed over Gadanki. The role of direct deposition of heat by exothermic chemical reactions and the relative importance of chemistry and dynamics in different seasons need to be explored. Two examples of upper mesospheric inversion layers observed using a Rayleigh lidar over Gadanki are shown in Fig. 6. The topside of the layer is normally close to adiabatic lapse indicating the potential for convective and/or dynamical instability. Such instability can also contribute to quasi-periodic radar echoes and atmospheric bores. To further examine the temperature structure found over Gadanki during the SAFAR pilot campaign period, we have studied the SABER onboard TIMED satellite observations data. Figure 7 shows the normalized frequency distribution of height and temperature of mesopause and stratopause over Gadanki region observed by SABER during May to November 2008. Mesopause altitude extending up to $100 \mathrm{~km}$ raises several 

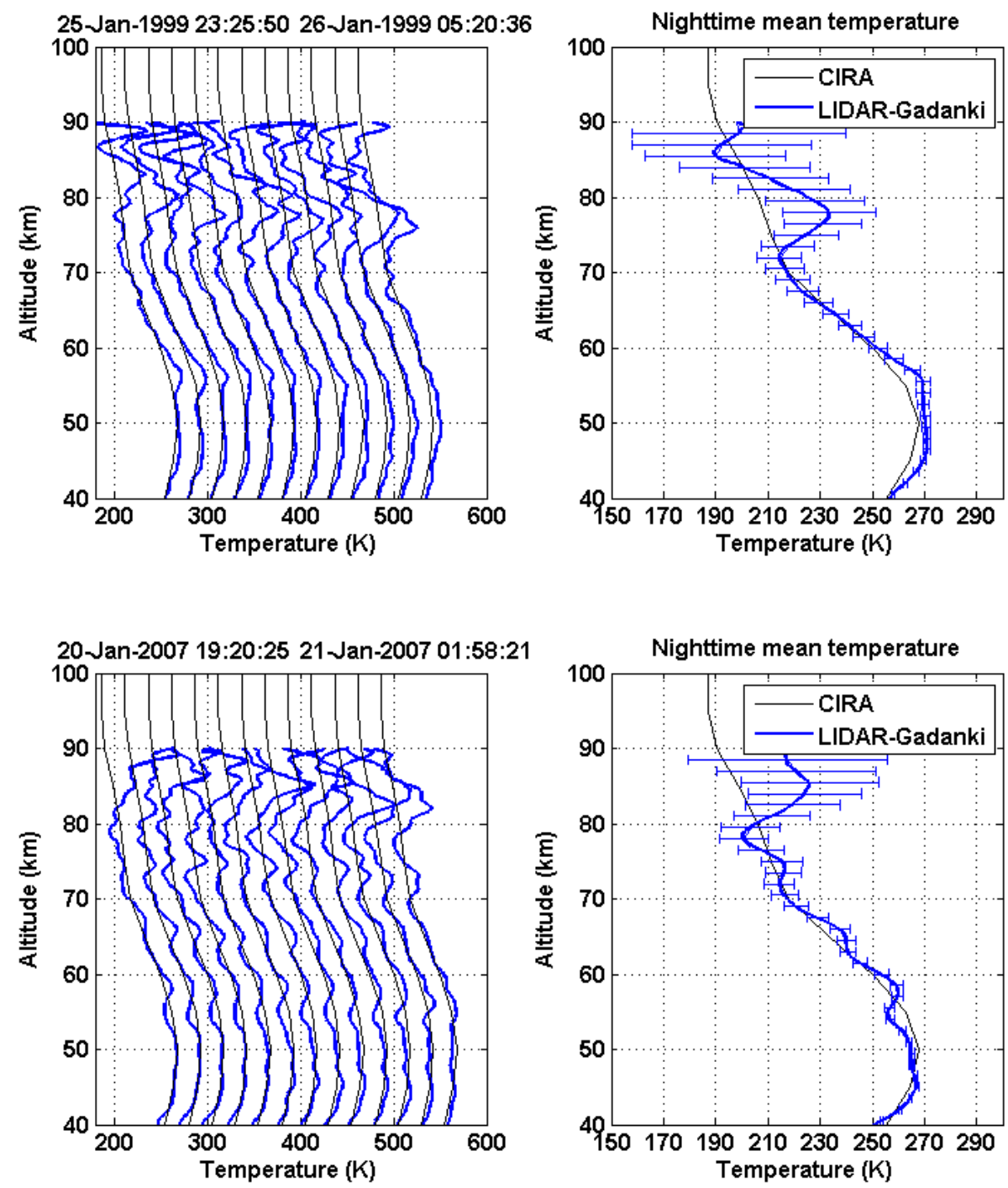

Fig. 6. Rayleigh lidar derived temperature profiles averaged for $30 \mathrm{~min}$ each (left panels) and nighttime mean temperature (right panels) over Gadanki.

important issues. For example, it reveals the mixing of neutral constituents extending up to $100 \mathrm{~km}$ and the dominance of IR cooling process. This in combination with chemical heat release by major reactions involving $\mathrm{O}, \mathrm{H}$, and $\mathrm{O}_{3}$ will have impact up to $100 \mathrm{~km}$ region. Influence of mesospheric inversion layers on the vertical distribution of intensities of the airglow emissions whose chemical reaction rate constants are temperature dependent remains unanswered. More recently study of mesospheric airglow emissions, similar to that reported by Taori et al. (2007) is initiated at Gadanki involving observations of $\mathrm{OH}$ emission (from about $85 \mathrm{~km}$ at 840 and $846.5 \mathrm{~nm}$ ) and $\mathrm{O}_{2}$ emission (from about $94 \mathrm{~km}$ at 866 and $868 \mathrm{~nm}$ ) which is expected to answer the above question.

As mentioned earlier, the vertical shear in the zonal wind is found to be the dominant mechanism in generating a wide spectrum of gravity waves during summer (monsoon) months. However, the mesospheric inversion, supposed to be due mainly to the gravity wave dissipation, occurs most frequently in spring equinox, although the TEJ associated shears peak up later in the summer. It may be mentioned here that only $20 \%$ less inversions is noticed during summer than equinoxes (Kumar et al., 2007) suggesting that waves during summer also propagate to higher altitudes. The background wind must be playing an important role in filtering the upward propagating waves. Detailed investigation of this aspect is warranted with more data set being collected in future campaigns. 

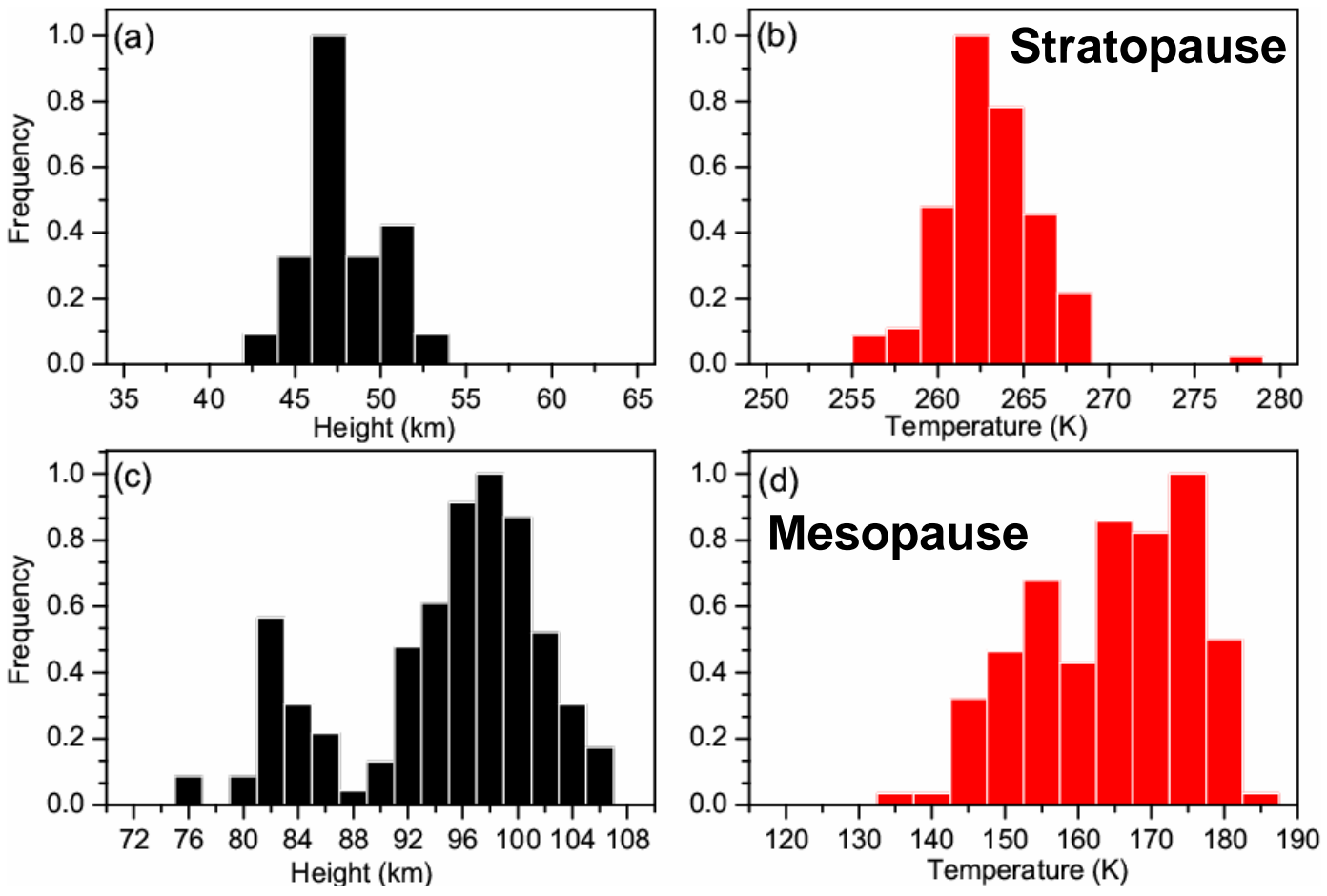

Fig. 7. Normalized distribution of stratopause (a) height and (b) temperature, and mesopause height (c) and temperature (d) observed over Gadanki region during SAFAR pilot campaign (May-November 2008) by SABER/TIMED satellite.

\subsection{Electro-dynamical coupling}

Upper mesosphere and lower thermosphere (UMLT), where wave activities are pronounced and important coupling between the neutral and ion takes place, is a region of intense investigation in the recent years. Electrodynamics in the Eregion becomes complex depending upon the complexity of the neutral wind system. Unfortunately, very little is known about these complexities mainly due to the observational limitations. These complex neutral-/electro-dynamics, however, are considered to be an important driver for the ionosphere thermosphere system. One of the frequently observed phenomena over Gadanki is the VHF radar echoes from the 88$100 \mathrm{~km}$ region. Though the observed features are similar to that reported over Arecibo (Mathews, 1998), echoes coming from altitudes as low as $88 \mathrm{~km}$ over Gadanki are intriguing. An attempt has been made to explain the genesis of such low altitude echoes as the effect of the weak Kelvin-Helmholtz Instability (KHI) (Patra et al., 2009). If it is the cause then any variation in the temperature structure observed in this region should play a role in the observed echoes as the excitation of KHI depends on the temperature structure. Thus we see linkages between the upward travelling waves in the middle atmosphere transferring energy and momentum in the upper mesosphere, thereby altering temperature structure and the VHF echoes from these region. We argue further that the linkages can reach to the F-region heights.
One of the unresolved issues in the F-region is the prediction of plasma bubble occurrence, which is detrimental for satellite based navigation and communication systems. While the important governing factors for formation of plasma bubbles are zonal electric field, vertical and meridional neutral winds, a seed perturbation is necessary for the growth of the Rayleigh-Taylor (RT) instability. Gravity waves have long been considered capable of doing this. As part of the SAFAR pilot campaign for the first time MST radar was operated during the summer period, in 2008 to study the summer-time F-region irregularities and make a detailed comparison with those observed in the equinox. It may be stressed that it is in the summer the convective storm activities are the most and the E-region activities are the strongest. The observations revealed that the morphology of the summer time F-region irregularities are quite different compared to that during equinox. The F-region irregularities are observed as horizontally stratified structures and occur predominantly in the post-midnight hours in contrast to their occurrence in the post-sunset hours during equinox. The intriguing observation is that they occurred after the disappearance of the F-layer trace in ionograms obtained independently from a collocated ionosonde. More details are found in a companion paper (Patra and Phanikumar, 2009). Summertime observations of spread F over mid-latitude (Haldoupis et al., 2003) were found to be well correlated with the E-region activity and it was proposed that the observed spread $\mathrm{F}$ was the 
manifestation of E-F-region coupling. Over the low latitude region, as the E-region activity is the strongest in summer and peaks after 22:00 LT (Venkateswara Rao et al., 2009), it is justifiable to consider that F-region irregularities are the manifestation of gradient drift instability with free energy driver coming from the unstable E-layer. This, however, needs a detailed investigation with simultaneous observations of $\mathrm{E}$ region activity and F-region plasma irregularities which is to be carried out in detail under the SAFAR program. It is necessary to study the wave dynamics and electrodynamics in the F-region, plasma structures, conductivities and polarization electric field in the E-region, and coupling of these electric fields to the equatorial F-region.

\section{Summary}

Study of Atmospheric Forcing and Responses (SAFAR) is a research program for five years from 2009 to 2014 being conducted at the National Atmospheric Research Laboratory, Gadanki, India aimed at studying the entire column of the atmosphere as a coupled system with a unified view of delineating the vertical coupling between atmospheric forcings and responses. Collocated observational systems such as the MST radar, lidar, Ionosonde, GPS radiosonde, a variety of aerosol and radiation measuring instruments, automatic weather station etc., will make intensive observations during the summer (May to November) and winter (December to February) months which are to be complimented with available satellite data. As a prelude to the main program a pilot campaign was made during May to November 2008 mainly to bring out the important science issues and to identify the missing links, both in terms of observational data and in our theoretical understandings, which are to be taken up in the main program. Following are some of the important findings of the pilot campaign. The companion papers appearing in the same issue give more details on each study.

It is now well recognized that atmospheric radiative forcing and hence global warming caused by the greenhouse gases is responsible for the climate change (IPCC, 2007). Atmospheric soot (black carbon) particles produced as a result of incomplete combustion by virtue of their absorption of solar radiation add to heating of the atmosphere. Owing to their short residence time, of about a week, the heating effect produced by this type of aerosols is confined to regional levels, around the source region, unlike greenhouse warming which is a global effect. When such source regions are present in the tropics, as in the present case, they pose a bigger effect, as strong convective activities often present in the tropical region take the particles to higher heights. However our knowledge on the effect of convective activities in mixing the pollutants to higher altitudes as well as the influence of the heating effect of pollutants on the atmospheric dynamics and convective activities are very poor. We found through observations and radiative model calculations that there exists a large atmospheric radiative forcing, of the order of $20 \mathrm{~W} / \mathrm{m}^{2}$ prior to the Indian summer monsoon causing atmospheric heating of the order of $0.5 \mathrm{~K} / \mathrm{day}$. What are the manifestations of this regional level radiative heating on atmospheric dynamics in general and convective activities in particular? At least we could show two examples where the effects are felt.

When we attempt to simulate the MST radar observed convective updraft associated with a thunderstorm using the state of the art Weather Research and Forecasting model (WRF version 3.0) we found large discrepancy. Out of the four different cloud microphysics schemes used in the model, only two schemes could at least qualitatively simulate the updraft but quantitatively the simulated values differ from the observations both in the vertical extend of the updraft and the magnitude. While the observations showed that the updraft can extend up to an altitude of about $14 \mathrm{~km}$ models could simulate updrafts only up to about $10 \mathrm{~km}$. Similarly the observed vertical velocities were of the order of $4 \mathrm{~m} \mathrm{~s}^{-1}$ and higher while best model simulated value is about $1.5 \mathrm{~m} \mathrm{~s}^{-1}$. The second example is the large difference found between the observed wind characteristics over Singapore and Gadanki. There is a general tendency to use observed winds over Singapore as typical for tropical altitudes. However, we find that the winds observed over Gadanki, a tropical location are quite different. For example, during the monsoon period influence of tropical easterly jet in zonal wind is seen over Gadanki but not over Singapore. Observed winds between 20 and $30 \mathrm{~km}$ during monsoon months are easterly over Gadanki but they are westerly over Singapore. Such large differences in the background wind condition will have different filtering processes on the waves that propagate upwards and thus the anomaly extends to greater heights.

In the mesosphere the amount of energy dumped by breaking of waves that came from below is comparable to the energy the region absorbs from the incoming solar radiation. The momentum transfer by these waves can drive the mesosphere out of radiative equilibrium and can alter the mesospheric thermal structure and meridional circulation. Variations in the upper mesospheric temperature structure have serious implications on the mixing of the neutral constituents, major chemical reactions involving $\mathrm{O}, \mathrm{H}$, and $\mathrm{O}_{3}$, the airglow emissions and on the electro-dynamical coupling between the mesosphere and the ionosphere. Over Gadanki the MST radar has often observed echoes from the $88-100 \mathrm{~km}$ region which are explained as the effect of weak Kelvin-Helmholtz instability, the excitation of which depends on the temperature structure. Thus we see a linkage between the upward travelling waves in the middle atmosphere, the altered temperature structure and the radar echoes from this region. This linkage can go further into F-region heights. As part of the SAFAR pilot campaign the MST radar was operated in ionospheric mode, the first summer time observation, which revealed that the morphology of the F-region irregularities are quite different compared to that during equinox. Over mid 
latitudes summertime spread $\mathrm{F}$ are explained in terms of coupling between the E- and F-regions (Haldoupis et al., 2003). Over the tropics as the E-region activity is the strongest in summer and peaks after 22:00 LT, it is justifiable to consider that the manifestation of gradient drift instability with free energy driver coming from the unstable E layer is responsible for the observed F-region irregularities. Simultaneous observations of E-region activity and $\mathrm{F}$ region plasma irregularities are necessary to further prove this point, which is planned during the SAFAR main program.

The SAFAR pilot campaign has shown undoubtedly the couplings that exist from surface layer to the top of the ionosphere during summer over a tropical location. It also emphasized the need for collocated measurements of the entire atmosphere using a set of complimentary techniques and instruments. The pilot campaign also helped us in identifying the gaps in our understanding and areas where we need to strengthen and compliment our observations. The purpose of this communication is not only to share the knowledge that we gained from the SAFAR pilot campaign, but also to inform the international atmospheric science community about the SAFAR program as well as to extend our invitation to join in our journey by making complementary observations at Gadanki or from any complementary sites and help in unfolding the complex behavior of the atmosphere over the tropics.

Acknowledgements. The authors would like to thank G. Madhavan Nair, Chairman, ISRO/NARL Governing Council and George Joseph, Chairman, NARL Scientific Advisory Committee (SAC) and the SAC members for their support and encouragement to the SAFAR program. The budget for the study is provided by the Department of Space, Government of India which is thankfully acknowledged.

Topical Editor C. Jacobi thanks B. V. Krishna Murthy and P. Balarama Rao for their help in evaluating this paper.

\section{References}

Chen, S. H. and Sun, W. Y.: A one dimensional time-dependent cloud model, J. Meteorol. Soc. Japan, 80, 99-118, 2002.

Corti, T., Luo, B. P., de Reus, M., Brunner, D., et al. :: Unprecedented evidence for deep convection hydrating the tropical stratosphere, Geophys. Res. Lett., 35, L10810, doi:10.1029/2008GL033641, 2008.

Debashis Nath., Ratnam, M. V., Jagannadha Rao, V. V. M., Krishna Murthy, B. V., and Rao, S. V. B.: Gravity wave characteristics observed over a tropical station using high-resolution GPS radiosonde soundings, J. Geophys. Res., 114, D06117, doi:10.1029/2008JD011056, 2009.

Haldoupis, C., Kelley, M. C., Hussey, G. C., and Shalimov, S.: Role of unstable sporadic-E layers in the generation of maidlatitude spread F, J. Geophys. Res., 108, 1446, doi:10.1029/2003JA009956, 2003.

Gadhavi, H. and Jayaraman, A.: Absorbing aerosols: Contribution of biomass burning and implications for radiative forcing, Ann. Geophys., in review, 2009.
Hong, S. Y., Dufhia, J., and Chen, S. H.: A revised approach to ice microphysical processes for the bulk parameterization of clouds and precipitation, Mon. Weather. Rev., 132, 103-120, 2004.

IPCC: Climate Change 2007, Cambridge University Press, Cambridge, UK, 2007.

Jayaraman, A., Gadhavi, H., Ganguly, D., Misra, A., Ramachandran, S., and Rajesh, T. A.: Spatial variations in aerosol characteristics and regional radiative forcing over India: Measurements and modeling of 2004 road campaign experiment, Atmos. Environ., 40, 6504-6515, 2006.

Kumar, G. K., Ratnam, M. V., Patra, A. K., Rao, V. V. M. J., Rao, S. V. B., and Rao, D. N.: Climatology of lowlatitude mesospheric echo characteristics observed by Indian mesosphere, stratosphere, and troposphere radar, J. Geophys. Res., 112, D06109, doi:10.1029/2006JD007609, 2007.

Mathews, J. D.: Sporadic E: Current views and recent progress, J. Atmos. Solar. Terr. Phys., 60, 413-435, 1998.

Meriwether, J. W. and Gerrard, A. J.: Mesosphere inversion layers and stratosphere temperature enhancements, Rev. Geophys., 42, RG3003, doi:10.1029/2003RG000133, 2004.

Morrison, H., Curry, J. A., and Khvorostyanov, V. I.: A new Double-Moment Microphysics parameterization for application in cloud and climate models. Part I: Description, Mon. Weather Rev., 62, 1665-1676, 2005.

Patra, A. K., Sripathi, S., Sivakumar, V., and Rao, P. B.: Statistical characteristics of VHF radar observations of low latitude E-region irregularities over Gadanki, J. Atmos. Solar Terr. Phys., 66, 1615-1626, 2004.

Patra, A. K., Tiwari, D., Sripathi, S., Rao, P. B., Sridharan, R., Devasia, C. V., Viswanathan, K. S., Subbarao, V., Sekar, R., and Kherani, E. A.: Simultaneous radar observations of meter-scale $F$ region irregularities at and off the magnetic equator over India, J. Geophys. Phys., 110, A02307, doi:10.1029/2004JA010565, 2005.

Patra, A. K., Venkateswara Rao, N., and Choudhary, R. K.: daytime low-altitude quasi-periodic echoes at Gadanki: Understanding of their generation mechanism in the light of their Doppler characteristics, Geophys. Res. Lett., 36, L05107, doi:10.1029/2008GL036670, 2009.

Patra, A. K. and Phanikumar, D. V.: Intriguing aspects of F-region plasma irregularities revealed by the Gadanki radar observations during the SAFAR campaign, Ann. Geophys., 27, 3781-3790, 2009 , http://www.ann-geophys.net/27/3781/2009/.

Rajeevan, M., Kesarkar, A. P., Rao, T. N., Radhakrishna, B., Thampi, S. B., and Rajasekhar, M.: Sensitivity of Cloud Microphysics in the Simulation of Convective Updrafts observed over Gadanki, India, Ann. Geophys., in review, 2009.

Rao, P. B., Jain, A. R., Kishore, P., Balamuralidhar, P., Damle, S. H., and Viswanathan, G.: Indian MST radar system 1, System description and sample wind measurements in ST mode, Radio Sci., 30, 1125-1138, 1995.

Rao, T. N., Radhakrishna, B., Satyanarayana, T. M., and Satheeshkumar, S.: The role of convection in stratospheretroposphere exchange processes, Ann. Geophys., in review, 2009.

Rao, T. N., Uma, K. N., Satyanarayana, T. M., and Rao, D. N.: Differences in draft core statistics from wet spell to dry spell over Gadanki (13.5 N, 79.2 E), India, Mon. Weather Rev., 137, 3501- 
3518, 2009.

Ratnam, M. V., Narayana Rao, D., Krishnaiah, M., Bhavani Kumar, Y., Siva Kumar, V., and Rao, P. B.: Coordinated MST radar and lidar observations for the study of mesospheric structures over a tropical station, J. Atmos. Sol. Terr. Phys., 64, 349-358, 2002.

Ratnam, M. V., Narendra Babu, A., Jagannadha Rao, V. V. M., Rao, S. V. B., and Narayana Rao, D.: MST radar and radiosonde observations of inertia-gravity wave climatology over tropical stations: Source mechanisms, J. Geophys. Res., 113, D07109, doi:10.1029/2007JD008986, 2008a.

Ratnam, M. V., Kumar, G. K., Murthy, B. V. K., Patra, A. K., Rao, V. V. M. J., Rao, S. V. B., Kumar, K. K., and Ramkumar, G.: Long-term variability of the low latitude mesospheric SAO and QBO and their relation with stratospheric QBO, Geophys. Res. Lett., 35, L21809, doi:10.1029/2008GL035390, 2008b.

Ratnam, M. V., Debashsis Nath., and Shibagaki, Y.: Convection and wind shear: Which mechanism dominates for generation of gravity waves during monsoon season?, Ann. Geophys., in review, 2009.

Sherwood, S. C. and Dessler, A. E.: A model for transport across the tropical tropopause, J. Atmos. Sci. 58, 765-779, 2001.

Sridharan, S., Sathishkumar, S., and Gurubaran, S.: Influence of gravity waves and tides on mesospheric temperature inversion layers: simultaneous Rayleigh lidar and MF radar observations, Ann. Geophys., 26, 3731-3739, 2008, http://www.ann-geophys.net/26/3731/2008/.
Sridharan, S., Vishnu Prasanth, P., and Bhavani Kumar, Y.: A report on long-term trends and variabilities in middle atmospheric temperature over Gadanki $\left(13.5^{\circ} \mathrm{N}, 79.2^{\circ} \mathrm{E}\right)$, J. Atmos. Solar-Terr. Phys., 71, 1463-1470, 2009.

Taori, A., Guharay, A., and Taylor, M. J.: On the use of simultaneous measurements of $\mathrm{OH}$ and $\mathrm{O}_{2}$ emissions to investigate wave growth and dissipation, Ann. Geophys., 25, 639-643, 2007, http://www.ann-geophys.net/25/639/2007/.

Thompson, G., Rasmussen, R. M., and Manning, K.: Explicit forecasts of winter precipitation using an improve bulk microphysics scheme. Part-I: Description and sensitivity analysis, Mon. Weather Rev., 132, 519-542, 2004.

Venkateswara Rao, N., Patra, A. K., Pant, T. K., and Rao, S. V. B.: Morphology and seasonal characteristics of low latitude E region quasi-periodic echoes studied using large database of Gadanki radar observations, J. Geophys. Res., 113, A07312, doi:10.1029/2007JA012830, 2009.

Uma, K. N. and Rao T. N.: Characteristics of vertical velocity cores in different convective systems observed over Gadanki, India, Mon. Weather Rev., 137, 953-977, 2009. 